\section{Is tree shelter protection an effective complement to weed competition management in improving the morpho- physiological response of holm oak planted seedlings?}

\author{
Carlos J Ceacero ${ }^{(1)}$, Rafael M Navarro-Cerrillo ${ }^{(2)}$, José Luis Díaz- \\ Hernández ${ }^{(3)}$, Antonio D Del Campo ${ }^{(4)}$
}

\begin{abstract}
Weed control is a key aspect affecting seedling response in newly-established plantations. Tree shelter protection may be an effective complement to weed control with a positive effect on the overall response of seedlings. Our study focused on assessing the morpho-physiological response of Holm oak (Quercus ilex L. ballota [Desf.] Samp.) plantations to weed control and individual protection as a combined cultural technique on a cropland site in southern Spain. The weed control treatments (cultivation, herbicide and mulch) were also applied in combination with tree shelters. Morpho-physiological variables including survival, aerial and root morphology, water potential, gas exchange and chlorophyll fluorescence were monitored over a 2-year period. Results showed that weed competition management treatments improved the seedling survival rate compared to the control treatment. Moreover, shelter protection was proven to enhance the height growth of seedlings. At early stages of establishment, and particularly under combined treatments, all plants invested more resources in their aerial parts than in their root system. Seedlings did not regulate water loss as a result of water stress, contrary to the expectations in Mediterranean areas. Under all treatments, especially those combined with tree shelters, seedlings took up to 2 years to achieve morpho-physiological adaptation to site conditions, in terms of height and diameter growths, and water stress behavior. In addition, tree shelters promoted an increase in net photosynthesis compared to non-shelter treatments during the winter period. Tree shelters also limited the emergence of photo-inhibition phenomena in seedlings so that plants under combined treatments showed greater photo-chemical efficiency. Thus, this study supports the effectiveness of tree shelter protection as a complement to weed control treatments. More specifically, a combination of individual protection (shelter) and weed control around seedlings is an interesting technique for reforestation of agroforestry systems in the Mediterranean area.
\end{abstract}

Keywords: Tree Shelter, Tillage, Mulch, Oxyfluorfen, Photosynthesis, Photoinhibition

\section{Introduction}

Holm oak (Quercus ilex) is a key species in Mediterranean forest ecosystems, especially in agroforestry systems such as the dehesa. Some authors have questioned the long-term sustainability of this ecosystem, raising concerns about the indequate regeneration of the species (Dupraz \& Newman 1997, Rivest et al. 2011), both in seedling numbers and growth. The limited natural regeneration of Mediterranean agroforestry systems has been linked to brush clearing, plowing, grazing and "oak decline" (Plieninger 2007).

In regards to the artificial regeneration of such ecosystems, the most commonly cited causes for the low plantation performance include poor species-site matching, changes in soil properties (water excess or drought, compacted soils), presence of aggressive weed communities and animal predation (South et al. 2001, Löf et al. 2012). Weed competition is usually the first cause of plant loss, increasing restoration costs due to replacement of dead plants and poor vegetative growth of surviving plants (Thompson \& Pitt 2003, Navarro Cerrillo et al. 2005). This is particularly important in Mediterranean areas, where resource constraints (mainly water) may exacerbate the negative effect of competition (Maestre et al. 2009).

Weed control management and tree protection techniques can modify water availability
(1) Departamento de Fisiología, Anatomía y Biología Celular, Facultad de Ciencias Experimentales, Universidad Pablo de Olavide, E-41013 Sevilla (Spain); (2) Departamento de Ingeniería Forestal, Universidad de Córdoba, Edf. Leonardo da Vinci, Campus de Rabanales, Carretera Nacional IV, Km 396, Aptdo 3048. 14071 Cordoba (Spain); (3) IFAPA. Camino de Purchil $\mathrm{s} / \mathrm{n}$. Consejería de Agricultura, Pesca y Medio Ambiente, Junta de Andalucía, Aptdo 2027, E-18080 Granada (Spain); (4) Re-ForeST, Research group in Forest Science and Technology, DIHMA- ETSIAMN, Universidad Politécnica de Valencia, Camí de Vera s/n, E-46022 Valencia (Spain)

@ Carlos J Ceacero (cjcearui@upo.es)

Received: Sep 12, 2013 - Accepted: Nov 26, 2013

Citation: Ceacero CJ, Navarro-Cerrillo RM, Díaz-Hernández JL, Del Campo AD, 2014. Is tree shelter protection an effective complement to weed competition management in improving the morphophysiological response of holm oak planted seedlings? iForest 7: 289-299 [online 201404-01] URL: http://www.sisef. it/iforest/contents/?id=ifor1126-007

Communicated by: Roberto Tognetti

for vegetation, soil characteristics, lighting conditions and temperature in the plant environment, among others (South et al. 2001, Dahiya et al. 2007, Oliet \& Jacobs 2007, Navarro Cerrillo et al. 2009, Löf et al. 2012). In turn, these changes may determine plant stress, leading to morpho-physiological responses. Basic procedures used to control vegetation in forest plantations include cultivation practices (manual weeding), herbicide application and individual protection (mulch and tree shelters). When compared with plantations where weed control is not practiced, treated forest plantations are commonly characterized by increased plant survival and enhanced growth (Willoughby et al. 2009, Olivera et al. 2011), although findings are far from being consistent (Ammer et al. 2011).

Tree shelters are widely used to protect tree seedlings against animal browsing and are known to strongly influence the microclimate (i.e., temperature, light intensity, radiation, relative humidity, vapor pressure deficit, $\mathrm{CO}_{2}$ concentration and wind) surrounding the plants (Oliet \& Jacobs 2007, Bergez \& Dupraz 2009, Close et al. 2009); thus, they ultimately have an impact on plant morphology and physiology. In the Mediterranean conditions, a number of studies have shown a positive effect of shelters on tree 
survival and height growth (Navarro Cerrillo et al. 2005, Oliet \& Jacobs 2007, Puértolas et al. 2010). However, tree shelters often have negative effects on both radial growth and stability of seedlings (Chaar et al. 2008).

Despite the current interest in forestry restoration, few studies have used a morphophysiological approach to describe the combined effect of weed control and tree shelters on tree establishment (Oliet \& Jacobs 2007, Laliberté et al. 2008, Navarro Cerrillo et al. 2009). Weed control and tree shelter effects on seedling response have been widely studied as independent factors in reforestation literature (Oliet \& Jacobs 2007, Willoughby et al. 2009, Puértolas et al. 2010, Ammer et al. 2011). Yet, there is a lack of research on the combined effects of both treatments Some issues must still be clarified: do tree shelters have a synergistic effect with weeding treatments over the seedling response? Do tree shelters enhance growth, photosynthesis and photo-chemical response of weeding treatments in seedlings? Some authors considered that a more comprehensive management of vegetation systems requires knowledge of new techniques and/or methods to combine multiple techniques (Kurstjens 2007). Our study focused on assessing the morpho-physiological response of Holm oak plantations to weed control and individual protection as a combined cultural technique This approach was based on a comprehensive management of vegetation systems in volving weed competition and biodiversity and soil conservation, among others.

\section{Material and methods}

\section{Experimental site}

The experimental plot was located in the Cordoba province (Andalusia, southern Spain, $37^{\circ} 51^{\prime} \mathrm{N}$ and $4^{\circ} 48^{\prime} \mathrm{E}$, elev. $92 \mathrm{~m}$ a.s.l.) on an abandoned cropland slightly sloping towards the main river (slope $<1 \%$ ), with no obvious erosion symptoms. The soil types were calcareous fluvisols with abundant gravel and irregular thickness not ex- ceeding $50 \mathrm{~cm}$ in depth. The area is characterized by dry Mediterranean climate with an average annual rainfall of $536 \mathrm{~mm}$, hot and dry summers and mild winters (average annual temperature $17.6{ }^{\circ} \mathrm{C}$ - Ceacero et al. 2012). The weed community was dominated by cruciferous species commons in wheat crops, such as Diplotaxis spp. and Sinapis spp.

\section{Site preparation, treatment}

establishment and experimental design

The experiment was performed between January 2003 and November 2004. Twelvemonth-old seedlings of Quercus ilex subsp. ballota supplied by a Forest Department nursery in $400 \mathrm{~cm}^{3}$ containers fulfilled with peat-vermiculite ( $3: 1$ volume) were planted manually in the field. Average height and basal diameter of the seedlings measured just after planting were $11.59 \pm 0.75 \mathrm{~cm}( \pm$ standard error, $\mathrm{N}=80)$ and $4.12 \pm 0.31 \mathrm{~mm}(\mathrm{~N}=$ 80 ), respectively, with no significant differences between treatments. Site preparation before planting included subsoiling to a depth of $50 \mathrm{~cm}$ by a one-spike ripper and harrowing the plot.

A multifactorial design was chosen for the trial with complete randomized blocks, 4 replications and 20 sampling units (plants) per factorial combination (treatment). Eighty plants per treatment were used, 560 seedlings in total. All seedlings were tagged to ensure measurement. We tested three weed management treatments, namely cultivation (L), mulch (M) and herbicide $(\mathrm{H})$, with and without the presence of a tree shelter (LT, MT, HT). Finally, we introduced a control treatment. The main characteristics of the treatments applied are described in Tab. 1.

Weed control practices were repeated for the herbicide $(\mathrm{H})$ and cultivation $(\mathrm{L})$ treatments in March 2004.

\section{Microclimate inside and outside tree shelters}

Air temperature $\left({ }^{\circ} \mathrm{C}\right.$, accuracy: $\left.0.1{ }^{\circ} \mathrm{C}\right)$, relative humidity ( $\mathrm{RH} \%$, accuracy: $5 \%$ ) and

Tab. 1 - Main characteristics of the treatments applied in this study.

\begin{tabular}{|c|c|}
\hline Treatment & Description \\
\hline Control (C) & $\begin{array}{l}\text { We maintained the weed cover that was present at the start of the experi- } \\
\text { ment. This treatment was not combined with tree shelters. }\end{array}$ \\
\hline Herbicide $(\mathrm{H})$ & $\begin{array}{l}\text { We sprayed with oxyfluorfen } 24 \%(\mathrm{Goal} 2 \mathrm{XL} \AA \text {, BASF) applied at } 2 \mathrm{~kg} \\
\text { active ingredient per ha in early May; the treatment was applied with a } \\
\text { backpack sprayer. }\end{array}$ \\
\hline Cultiv & $\begin{array}{l}\text { We made two passes/year with a small rotary cultivator drawn by a } 40-\mathrm{hp} \\
\text { farm tractor to manage weeds by shallow tilling }(5 \mathrm{~cm} \text { depth) at the peak } \\
\text { of the growing season in May. }\end{array}$ \\
\hline Mulcl & $\begin{array}{l}\text { We installed a } 1 \mathrm{~m}^{2} \text {-wide strip of } 40-\mu \mathrm{m} \text { black polyethylene sheeting with } \\
\text { mulch to a depth of } 3 \mathrm{~cm} \text {. The sheets were buried by hand. }\end{array}$ \\
\hline Tree shelter $(\mathrm{T})$ & $\begin{array}{l}\text { We used cylindrical tree shelters (microperforated Fortetub) } 60 \mathrm{~cm} \text { tall } \\
\text { and } 86-110 \mathrm{~mm} \text { in diameter made of a double layer of polypropylene. } \\
\text { They were light brown in color and ventilated with numerous holes scat- } \\
\text { tered along the upper third of the tube. }\end{array}$ \\
\hline
\end{tabular}

vapor pressure deficit (VPD, KPa) were recorded inside two tree shelters during two periods (April and July). Vapor pressure deficit data were calculated from simultaneous values of relative humidity and air temperature which were taken using a Stow Away XTI and Stow Away RH (Onset Computer Corporation ${ }^{\circledR}$, Cape Cod, Mass.) devices. Finally, data were compared with measurements taken outside the shelters.

\section{Survival and aerial-root morphology}

Seedling survival was recorded every 3 months. Height and diameter $1 \mathrm{~cm}$ above the ground were also recorded every 3 months using electronic calipers. Measurements were initially taken for 80 seedlings per treatment; monitoring was discontinued for treatments where survival was less than $5 \%$ (= 4 plants $)$.

In November 2004, a random sample of four plants per treatment was eradicated manually where enough living plants were available. Root morphology was assessed by image analysis using the WinRhizo ${ }^{\circledR}$ V3.10b software (Regent Instruments 1998). Color images of seedling roots were obtained with a HP ScanJet $6100 \mathrm{C}$ scanner. Selected parameters for root analysis were: (i) total length $(\mathrm{cm})$; (ii) surface area $\left(\mathrm{cm}^{2}\right)$; (iii) total root volume $\left(\mathrm{cm}^{3}\right)$; (iv) average diameter (cm); (v) number of tips; (vi) number of forks; and (vii) fibrosity, i.e., percentage of the total root length with diameter lower than $0.5 \mathrm{~mm}(\% \mathrm{~L} \leq 0.5 \mathrm{~mm})$.

\section{Water potential}

Predawn $\left(\Psi_{\mathrm{pd}}\right)$ and midday $\left(\Psi_{\mathrm{m}}\right)$ stem water potential were measured in the years 2003 and 2004 during the maximum vegetative activity (April-spring) and the maximum water limitation (July-summer) periods. Water potential was measured with a pressure chamber (SKPM 1400, Skye Instruments ${ }^{\circledR}$ ) on 4 random seedlings per treatment in each period (spring and summer).

\section{Gas exchange measurements}

One-year-old sun leaves without visible damage were labeled and measured monthly in four plants per treatment from July 2003 to November 2004, taking care to clamp always the same leaf portion (the central part across the rib). Net photosynthesis $(A, \mu \mathrm{mol}$ $\left.\mathrm{CO}_{2} \mathrm{~m}^{-2} \mathrm{~s}^{-1}\right)$ and photosynthetic photon flux density ( $\left.P P F D, \mu \mathrm{mol} \mathrm{m} \mathrm{m}^{-2} \mathrm{~s}^{-1}\right)$ were measured between 6 am and $6 \mathrm{pm}$, and daily mean photosynthesis rate was obtained. An infrared gas analyzer (CIRAS-1, PP systems ${ }^{\circledR}$, Hitchin, UK) equipped with a Parkinson leaf chamber was used to estimate net $\mathrm{CO}_{2}$ assimilation rate at $350 \mathrm{ppm} \mathrm{CO}_{2}$ concentration and photosynthetic photon flux density. Ambient radiation, humidity and temperature were used in the gas exchange measurements. 
Chlorophyll fluorescence measurements

Four plants per treatment were measured each month from July 2003 to November 2004 using a Plant Efficiency Analyser fluorometer (PEA, Hansatech Instruments ${ }^{\circledR}$, UK). Measurements were taken at ambient temperature from in vivo leaves attached to the main stem and with no visible damage.

Rapid kinetic curves of chlorophyll fluorescence were analyzed by applying the JIP test (Strasser et al. 2000) and starting from the fluorescence signal measured at $50 \mu \mathrm{s}$ after the start of the light as the initial fluorescence value (Fo). Biolyzer software (Maldonado-Rodríguez 1999) was used to calculate JIP parameters. Parameters selected for analysis were: (i) maximum quantum yield of primary photochemistry $(\mathrm{Fv} / \mathrm{Fm})$; (ii) maximum quantum yield of non-photochemical excitation (Dio/ABS); (iii) probability that an absorbed photon moves an electron further than $\mathrm{Q}_{\mathrm{A}^{-}}$(Eto/ABS); (iv) density of reaction centers per chlorophyll (RC/ABS); and (v) performance index $(\mathrm{PIabs}=[\mathrm{RC} / \mathrm{ABS}]$ $\left[\varphi_{\mathrm{P}_{\mathrm{o}}} /\left(1-\varphi_{\mathrm{P}_{\mathrm{o}}}\right)\right]\left[\psi_{\mathrm{o}} /\left(1-\psi_{\mathrm{o}}\right)\right]$ - Strasser et al. 2000). Finally, fluorescence parameters were used in accordance with Hermans et al. (2003) to analyze the vitality of plants subjected to the different treatments, comparing mean values of all assessments during the two-year monitoring period.

\section{Statistical analysis}

All variables were analyzed using a twoway ANCOVA with the following fixed effects: weed control treatment (cultivation, herbicide, mulch) and shelter protection (no shelter - individual weed treatment, shelter weed treatment combined with tree shelter). Soil gravel content was introduced as a covariate in all statistical analyses to control for the effect of soil differences. When significant differences were found after ANCO$\mathrm{VA}$, factors means were compared by $\mathrm{Tu}-$ key's test. Data were examined in advance to ascertain their normal distribution and ho- mogeneity of variances. Finally, linear regression models were used to compare the relationships between variables related to the water potential of seedlings.

For a more comprehensible analysis, height and diameter annual increments were calculated to assess seedlings' growth, and gas exchange and chlorophyll fluorescence values were grouped by season, providing four readings per year.

The effects of factors on the measured variables were tested for significance at the 0.05 level. Data were stored and processed using the Microsoft Excel ${ }^{\circledR} 2003$ package. Statistical analysis was performed using the SPSS ${ }^{\circledR}$ v.12.0 software (SPSS Inc. 2003)

\section{Results}

Microclimate inside and outside the tree shelter

Overall, a higher temperature was recorded inside than outside the tree shelter (Fig. 1).
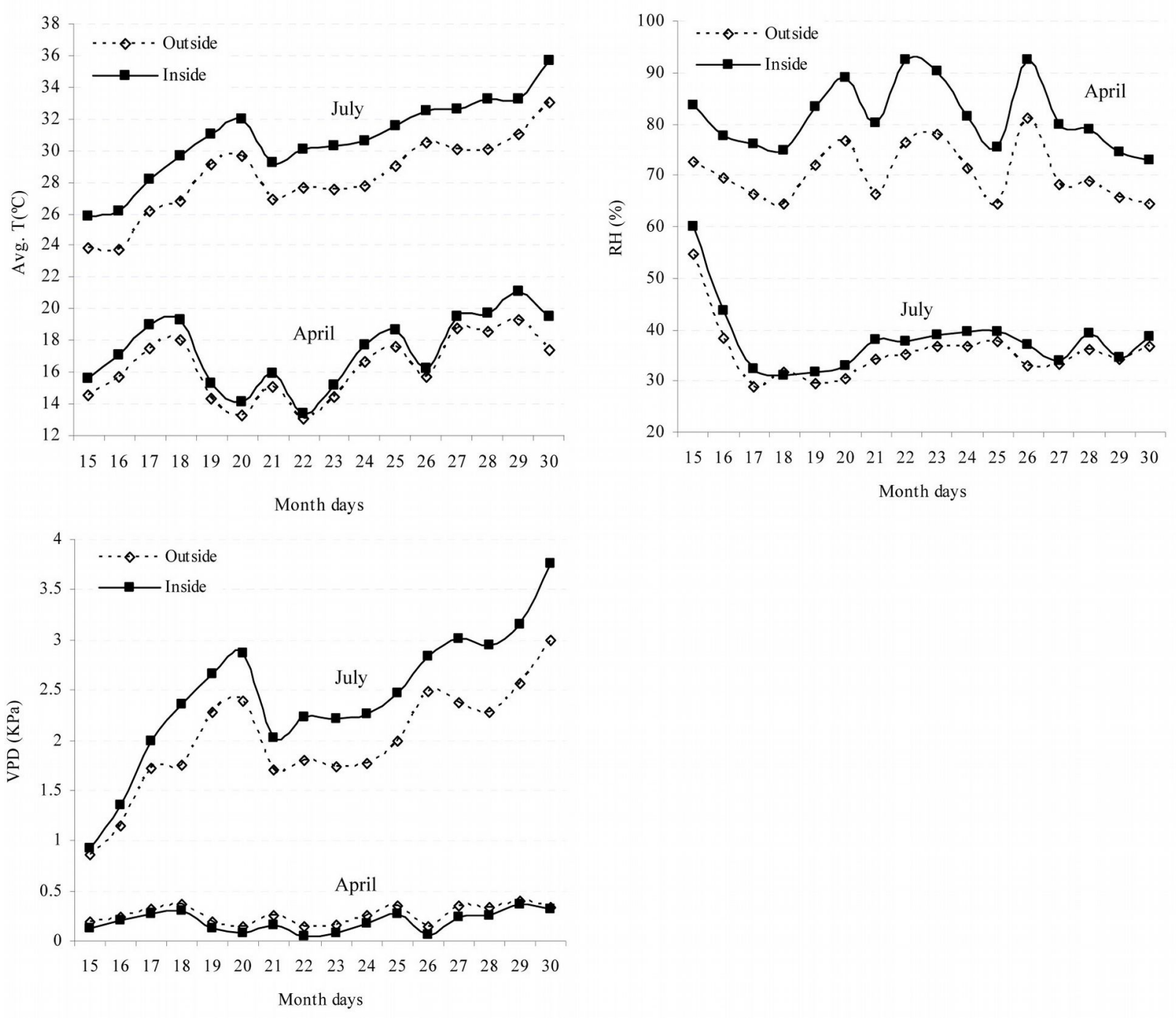

Fig. 1 - Mean temperature (T), relative humidity (RH) and vapor pressure deficit (VPD) outside and inside the tree shelter during two signi ficant two-week periods (spring-April; summer-July) in the first year after seedling establishment. 


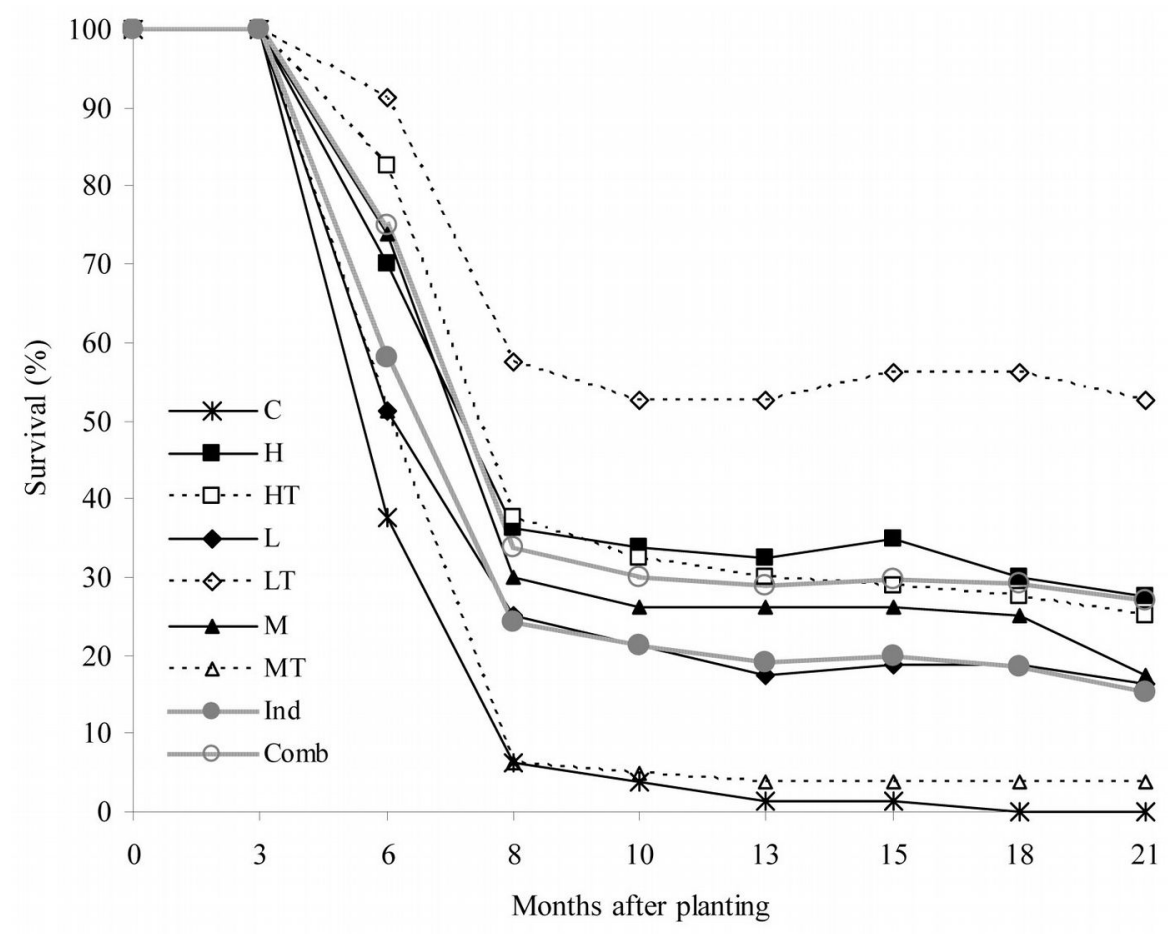

This was clearly perceptible in summer, when significant differences between the two above treatments were detected. By contrast, no significant differences were observed during the spring. Relative humidity (RH) values recorded inside the tree shelter were significantly higher than those taken outside during the spring. Since that moment onwards and throughout the summer, both environments showed similar values and no significant differences were detected. Finally, vapor pressure deficit (VPD) values in the spring were slightly lower inside the shelter than outside. However, the summer pressure deficit was clearly higher inside the shelter than outside (Fig. 1).

\section{Survival, growth and aerial and root morphology}

A substantial decrease in the survival rate of seedlings was observed 3 to 8 months after planting (critical summer period - Fig. 2). The lowest survival rates were recorded in the control treatment $(\mathrm{C})$ and the mulch + tree shelter (MT) treatment, with only $6 \%$ survived seedlings after the critical period. In the last two assessments, mortality as high as $100 \%$ was recorded in the treatment C. Conversely, for the cultivation + tree shelter (LT) treatment the survival rate was $55 \%$ during the critical period and persisted at $50 \%$ afterwards. As for the other treatments, intermediate survival rates were recorded. Interestingly, the survival rate of seedlings subjected to the combined treatments (weed control + tree shelters) was $10 \%$ higher than that observed for individual treatments (no shelter + weed control).

Significant differences in height growth among sheltered and non-sheltered seedlings were detected for both the years analyzed (Tab. 2), as seedlings subjected to weed treatments combined with tree shelters showed greater height increment than those subjected to either treatments (Fig. 3). As for growth in diameter, significant differences were observed only for the first year of growth (Tab. 2). The soil gravel content in-
Fig. 2 - Temporal changes in mean survival rate $(\%)$ of seedlings in the treatments considered (weed control treatments and shelter protection). (C): control; (H): herbicide; (HT): herbicide + tree shelters; (L): cultivation; (LT): cultivation + tree shelters; (M): mulch; (MT): mulch + tree shelters; (Ind): H, L, and $M$ pooled treatments (no shelter, weed control); (Comb): HT, LT, and MT pooled treatments (shelter, weed control).

Tab. 2 - Two-way ANCOVA for increment in diameter and height of Quercus ilex seedlings in the first two years after planting with the following fixed effects: weed control treatment (cultivation, herbicide, mulch) and shelter protection (individual $=$ no shelter + weed control, combined $=$ shelter + weed control). Covariate: Soil gravel content. (Year 1): 2003; (Year 2): 2004.

cluded in the analysis as a covariate was also significant for the same period. Weed control treatments had positive growth increments compared to combined weed control + tree shelter treatments, which exhibited negative increments (Fig. 3). In 2004, we noted a significant increase $(\mathrm{F}=70.653, \mathrm{P}<0.001)$ in diameter growth compared to 2003 , with a marked change in the trend of the combined weed control + tree shelter treatments. Diameter increments changed from negative rates in 2003 to positive rates in 2004 (Fig. $3)$.

Significant differences in root surface area and total root volume were also found between sheltered and non-sheltered seedlings. Weed control treatments combined with tree shelters showed lower mean values for the above parameters than weed control alone (Tab. 3). Mean root diameter was the only root morphology variable significantly affected by weed control treatments (Tab. 3). Seedlings undergoing herbicide and cultivation treatments showed the largest mean root

\begin{tabular}{|c|c|c|c|c|c|c|c|c|}
\hline \multirow{3}{*}{ Fixed effect (F) / Covariate (C) } & \multicolumn{8}{|c|}{ Dependent variable /Sampling period } \\
\hline & \multicolumn{2}{|c|}{$\begin{array}{c}\text { Diameter } \\
\text { increment } \\
\text { Year } 1\end{array}$} & \multicolumn{2}{|c|}{$\begin{array}{c}\text { Height } \\
\text { increment } \\
\text { Year 1 }\end{array}$} & \multicolumn{2}{|c|}{$\begin{array}{c}\text { Diameter } \\
\text { increment } \\
\text { Year } 2 \\
\end{array}$} & \multicolumn{2}{|c|}{$\begin{array}{c}\text { Height } \\
\text { increment } \\
\text { Year } 2\end{array}$} \\
\hline & $\mathbf{F}$ & $\mathbf{P}$ & $\mathbf{F}$ & $\mathbf{P}$ & $\mathbf{F}$ & $\mathbf{P}$ & $\mathbf{F}$ & $\mathbf{P}$ \\
\hline Weed treatment $(\mathrm{F})$ & 2.638 & 0.052 & 1.648 & 0.181 & 1.865 & 0.160 & 0.663 & 0.517 \\
\hline Shelter protection $(\mathrm{F})$ & 8.180 & 0.005 & 18.687 & $<0.001$ & 0.204 & 0.652 & 19.629 & $<0.001$ \\
\hline Weed treatment $\mathrm{x}$ shelter & 1.555 & 0.215 & 0.237 & 0.789 & 3.157 & 0.047 & 2.320 & 0.103 \\
\hline Soil gravel content $(\mathrm{C})$ & 7.000 & 0.009 & 0.054 & 0.817 & 1.528 & 0.219 & 0.660 & 0.418 \\
\hline
\end{tabular}




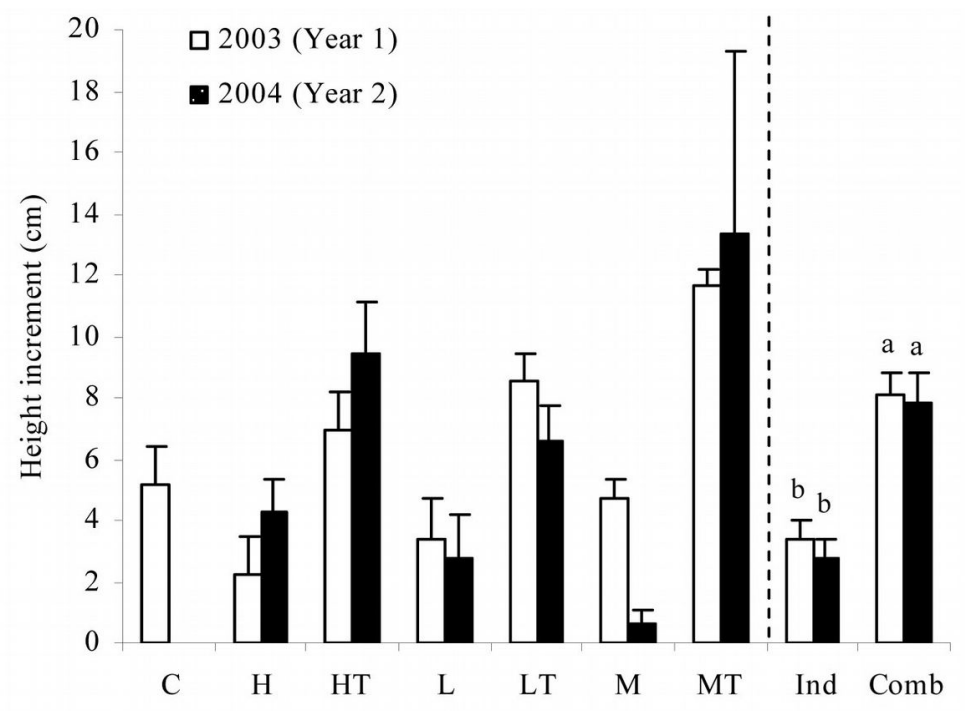

Fig. 3 - Mean values of increment in height and diameter for each treatment in the two years after seedling plantation. Different letters indicate significant differences between treatment means with $\mathrm{P} \leq 0.05$. (C): control; $(\mathrm{H})$ : herbicide; $(\mathrm{HT})$ : herbicide + tree shelters; (L): cultivation; (LT): cultivation + tree shelters; (M): mulch; (MT): mulch + tree shelters; (Ind): $\mathrm{H}, \mathrm{L}$, and M pooled treatments (no shelter, weed control); (Comb): HT, LT, and MT pooled treatments (shelter, weed control).

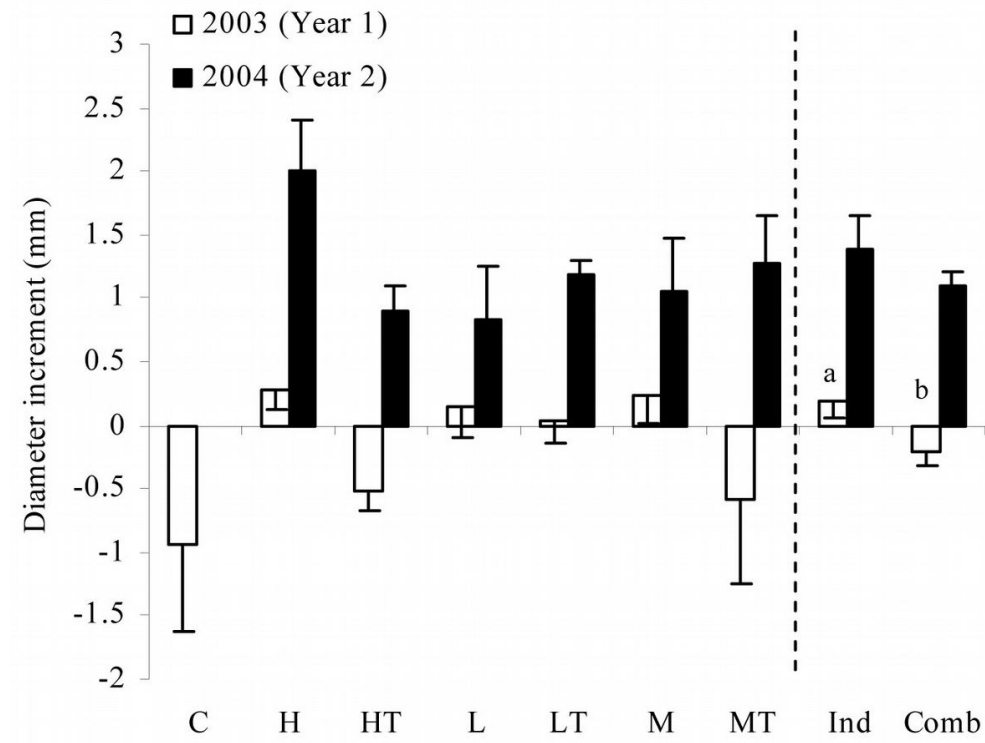

Tab. 3 - Average root morphological characteristics of Quercus ilex seedlings for each treatment analyzed. Different letters indicate significant differences between treatment means with $\mathrm{P} \leq 0.05$. (Ind): no shelter + weed control; (Comb): shelter + weed control. (TL): total length; (SA): surface area; (TV): total root volume; (Avg. D): average diameter; $(\% \mathrm{~L} \leq 0.5 \mathrm{~mm})$ : root fibrosity. $(*)$ : Two-way ANCOVA results: SA (significant factor: Shelter): $\mathrm{F}=5.818 \mathrm{P}=0.027$; TV (significant factor: Shelter): $\mathrm{F}=6.001 \mathrm{P}=0.009$; Avg. $\mathrm{D}$ (significant factor: Weed treatment): $\mathrm{F}=6.145 \mathrm{P}=0.009$.

\begin{tabular}{|c|c|c|c|c|c|c|c|c|}
\hline Treatment & Statistics & TL (cm) & $\mathrm{SA}^{*}\left(\mathrm{~cm}^{2}\right)$ & $\mathrm{TV}^{*}\left(\mathrm{~cm}^{3}\right)$ & Avg. D* (cm) & Tips & Forks & $\% \mathrm{~L} \leq 0.5 \mathrm{~mm}$ \\
\hline \multirow[t]{2}{*}{$\mathrm{H}$} & Mean & 503.48 & 93.95 & 1.54 & $0.064 a$ & 580 & 4077 & 60.74 \\
\hline & Std. Error & 112.05 & 22.06 & 0.42 & 0.005 & 170 & 1360 & 5.40 \\
\hline \multirow[t]{2}{*}{$\mathrm{L}$} & Mean & 348.87 & 63.93 & 1.02 & $0.063 a$ & 402 & 2492 & 61.90 \\
\hline & Std. Error & 68.58 & 12.15 & 0.22 & 0.004 & 76 & 542 & 3.87 \\
\hline \multirow[t]{2}{*}{$\mathrm{M}$} & Mean & 553.49 & 79.55 & 0.96 & $0.047 \mathrm{~b}$ & 776 & 4022 & 73.25 \\
\hline & Std. Error & 46.55 & 8.55 & 0.14 & 0.002 & 37 & 814 & 0.65 \\
\hline \multirow[t]{2}{*}{ Ind } & Mean & 468.61 & $79.14 a$ & $1.17 \mathrm{a}$ & 0.058 & 586 & 3530 & 65.29 \\
\hline & Std. Error & 49.55 & 8.83 & 0.17 & 0.003 & 73 & 551 & 2.63 \\
\hline \multirow[t]{2}{*}{ HT } & Mean & 354.05 & 56.05 & 0.75 & 0.053 & 497 & 2562 & 69.05 \\
\hline & Std. Error & 27.78 & 5.22 & 0.08 & 0.001 & 38 & 169 & 2.53 \\
\hline \multirow[t]{2}{*}{ LT } & Mean & 338.65 & 54.71 & 0.78 & 0.056 & 378 & 2268 & 67.50 \\
\hline & Std. Error & 51.52 & 7.83 & 0.14 & 0.006 & 91 & 681 & 4.34 \\
\hline \multirow[t]{2}{*}{ MT } & Mean & 409.33 & 57.11 & 0.68 & 0.048 & 525 & 3073 & 71.51 \\
\hline & Std. Error & 67.76 & 7.58 & 0.08 & 0.003 & 72 & 705 & 2.50 \\
\hline \multirow[t]{2}{*}{ Comb } & Mean & 370.57 & $56.04 b$ & $0.73 b$ & 0.052 & 471 & 2668 & 69.52 \\
\hline & Std. Error & 30.55 & 3.78 & 0.06 & 0.002 & 42 & 334 & 1.73 \\
\hline
\end{tabular}


Tab. 4 - Results of the two-way ANCOVA carried out on water potential and net photosynthesis rate of Quercus ilex seedlings with the following fixed effects: weed control treatment (cultivation, herbicide, mulch) and shelter protection (individual: no shelter + weed control; combined: shelter + weed control). Covariate: Soil gravel content.

\begin{tabular}{|c|c|c|c|c|c|c|c|c|c|c|c|c|c|c|c|}
\hline \multirow{3}{*}{ Component } & \multirow{3}{*}{$\begin{array}{l}\text { Fixed effect }(F) \text { and } \\
\text { covariate }(C)\end{array}$} & \multicolumn{14}{|c|}{ Sampling Period } \\
\hline & & \multicolumn{2}{|c|}{ Spring 03} & \multicolumn{2}{|c|}{ Summer 03} & \multicolumn{2}{|c|}{ Autumn 03} & \multicolumn{2}{|c|}{ Winter 04} & \multicolumn{2}{|c|}{ Spring 04} & \multicolumn{2}{|c|}{ Summer 04} & \multicolumn{2}{|c|}{ Autumn 04} \\
\hline & & $\mathbf{F}$ & $\mathbf{P}$ & $\mathbf{F}$ & $\mathbf{P}$ & $\mathbf{F}$ & $\mathbf{P}$ & $\mathbf{F}$ & $\mathbf{P}$ & $\mathbf{F}$ & $\mathbf{P}$ & $\mathbf{F}$ & $\mathbf{P}$ & $\mathbf{F}$ & $\mathbf{P}$ \\
\hline \multirow{4}{*}{$\begin{array}{l}\text { Water } \\
\text { potential }\end{array}$} & $\mathrm{V}$ & 0.058 & 0.982 & 2.553 & 0.066 & - & - & - & - & 0.034 & 0.991 & 0.250 & 0.859 & - & - \\
\hline & & 0.389 & 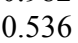 & 0.564 & 0.457 & - & - & - & - & 0.207 & 0.663 & 0.544 & 0.485 & - & - \\
\hline & & 0. & & 0.685 & 0.509 & - & - & - & - & 0.178 & 0.686 & 0.045 & 0.837 & - & - \\
\hline & & 2.12 & .152 & 2.405 & 0.128 & - & - & - & - & 0.064 & 0.803 & 0.064 & 0.803 & - & - \\
\hline \multirow{4}{*}{$\begin{array}{l}\text { Net } \\
\text { photosynthesis } \\
\text { rate }\end{array}$} & Weed $t_{1}$ & - & - & 1.463 & 0.235 & 0.187 & 0.905 & 0.260 & 0.854 & 2.236 & 0.089 & 1.371 & 0.257 & 2.275 & 0.085 \\
\hline & Shelter & - & - & 4.742 & 0.034 & 4.848 & 0.030 & 2.147 & 0.146 & 51.272 & $<0.001$ & 4.962 & 0.029 & 9.171 & 0.003 \\
\hline & Weed treatme & - & - & 2.652 & 0.080 & 0.504 & 0.606 & 0.220 & 0.803 & 0.423 & 0.657 & 3.878 & 0.025 & 1.591 & 0.209 \\
\hline & Soil gravel content (C) & - & - & 0.708 & 0.404 & 0.119 & 0.731 & 0.203 & 0.653 & 0.698 & 0.405 & 10.040 & 0.002 & 0.269 & 0.605 \\
\hline
\end{tabular}

diameter, in contrast to those with a synthetic mulch treatment.

\section{Water stress}

Seedling water status was not affected by the weed control treatments or the protection of tree shelters (Tab. 4). In 2003, however, dynamic regulation of the daily water potential of seedlings (i.e., the relationship between predawn water potential and the water potential difference between midday and predawn) reflected an increase in $\Psi_{m}-\Psi_{p d}$, when water deficit conditions became worse (i.e., more negative $\Psi_{\mathrm{pd}}$ values; $\mathrm{F}=33.202$ $\mathrm{P}<0.001)$. The same situation also holds for tree sheltering, as both weed treatments and weed treatments combined with shelters showed significant trends (Fig. 4). In 2004 a change in the trend of dynamic regulation of the daily water potential compared to 2003 was detected. During this year we observed a decrease in $\Psi_{\mathrm{m}}-\Psi_{\mathrm{pd}}$ values when more negative $\Psi_{\mathrm{pd}}$ values were obtained. No statistical significance was observed in this case (Fig. $4)$.

\section{Gas exchange}

Two-way ANCOVA revealed a significant effect of tree sheltering for all the seasons considered, except for winter 2004 (Tab. 4). The soil gravel content effect was merely significant for summer 2004.

Results showed a more balanced trend of mean net photosynthesis values throughout the whole monitoring period for combined shelter treatments than for individualized weed treatments (Fig. 5). In all cases, the absence of seedling protection with tree shelters was significantly associated with a higher $\mathrm{CO}_{2}$ assimilation rate, which was particularly noticeable in spring 2004 (Fig. 5, Tab. 4). The only exception to the above trend was in winter 2004, when the presence of shelters enhanced the photosynthesis rate.

\section{Chlorophyll fluorescence}

Tree shelter was the only factor significantly affecting the chlorophyll fluorescence response of seedlings in winter and spring of

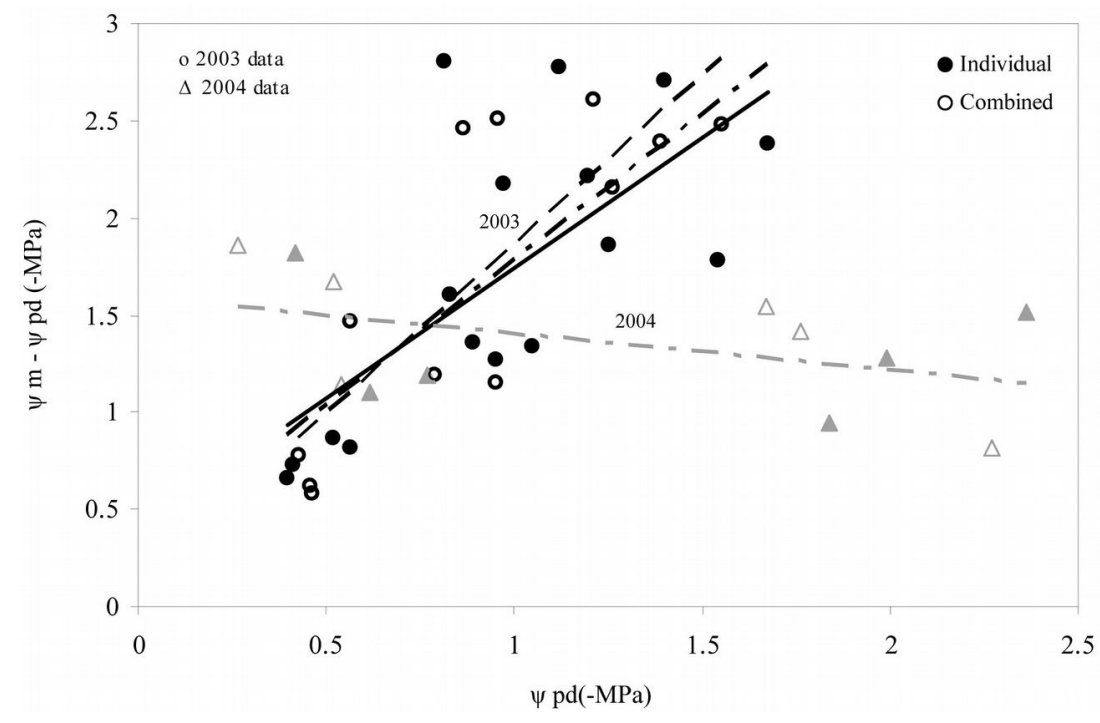

Fig. 4 - Predawn $\left(\Psi_{\mathrm{pd}}\right)$ and midday $\left(\Psi_{\mathrm{m}}\right)$ water potential of seedlings for maximum development (spring) and critical (summer) periods across the 2 years analyzed. Raw data were grouped according to the presence of a tree shelter protection. (Individual): no shelter + weed control; (Combined): shelter + weed control.

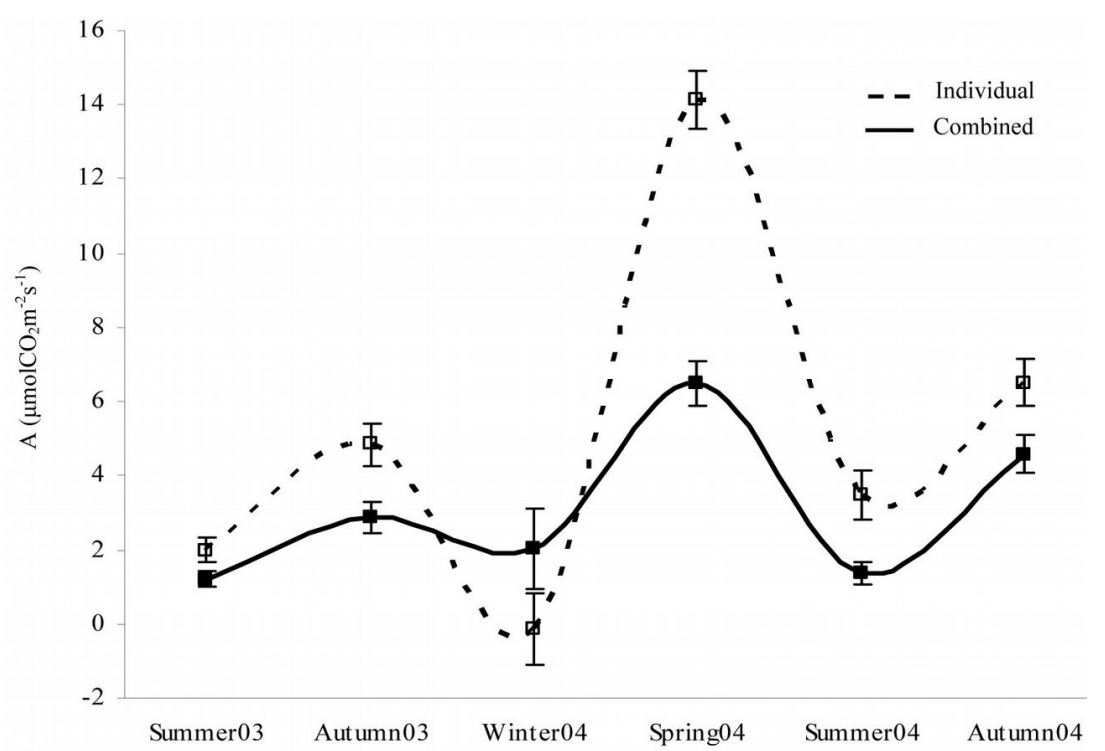

Fig. 5 - Temporal changes in net photosynthesis (A) mean values for the treatments. Raw data were grouped according to the presence of a tree shelter protection. (Individual): no shelter + weed control; (Combined): shelter + weed control. 

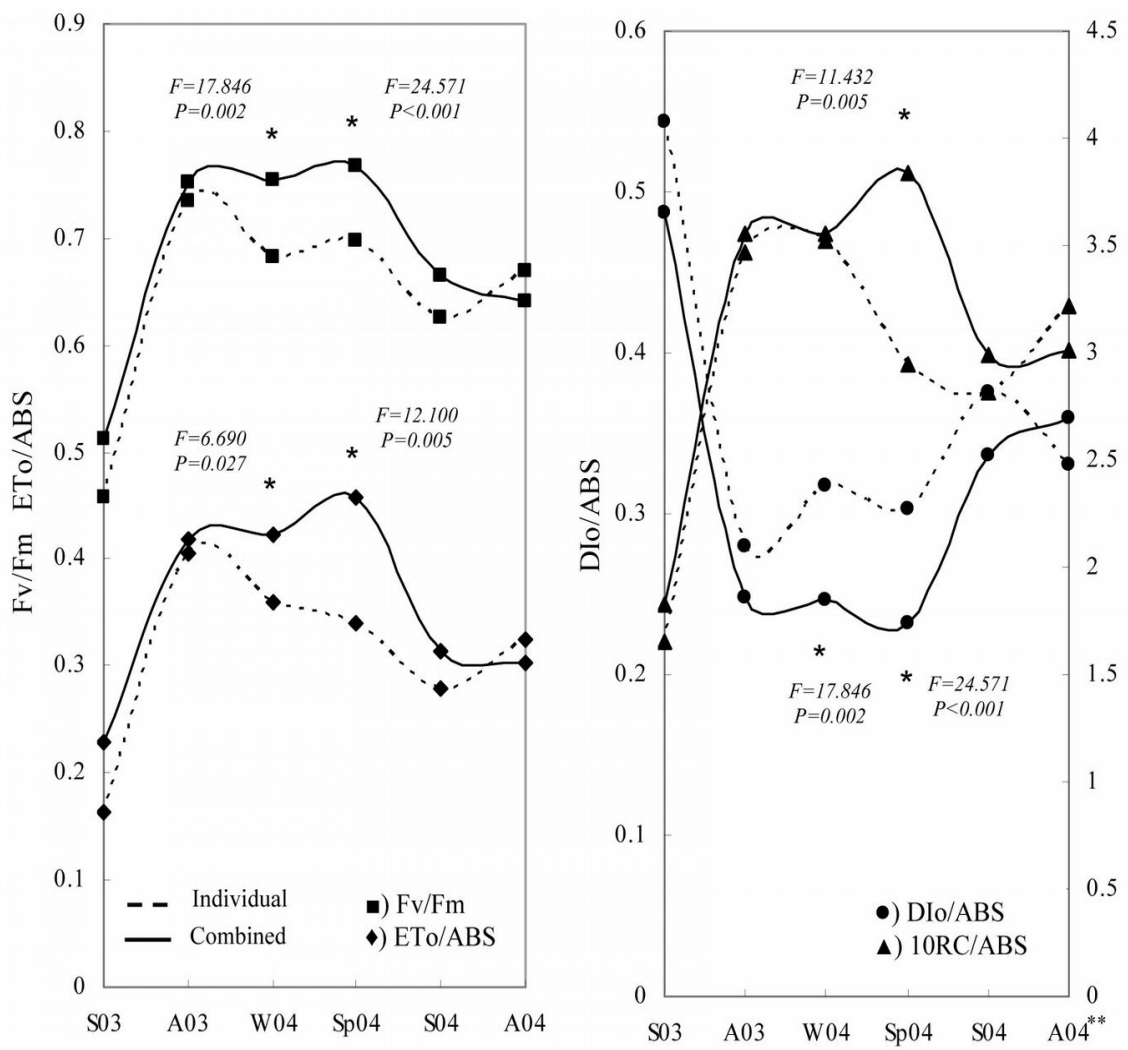

Fig. 6 - Temporal changes in mean values of chlorophyll fluorescence parameters for Quercus ilex seedlings. (Individual): no shelter + weed control; (Combined): shelter + weed control. $\left({ }^{*}\right)$ : significant differences at a given sampling date with $\mathrm{P} \leq 0.05$. (S): summer; (A): autumn; (W): winter; (Sp): spring; (03): year 2003; (04): year 2004.

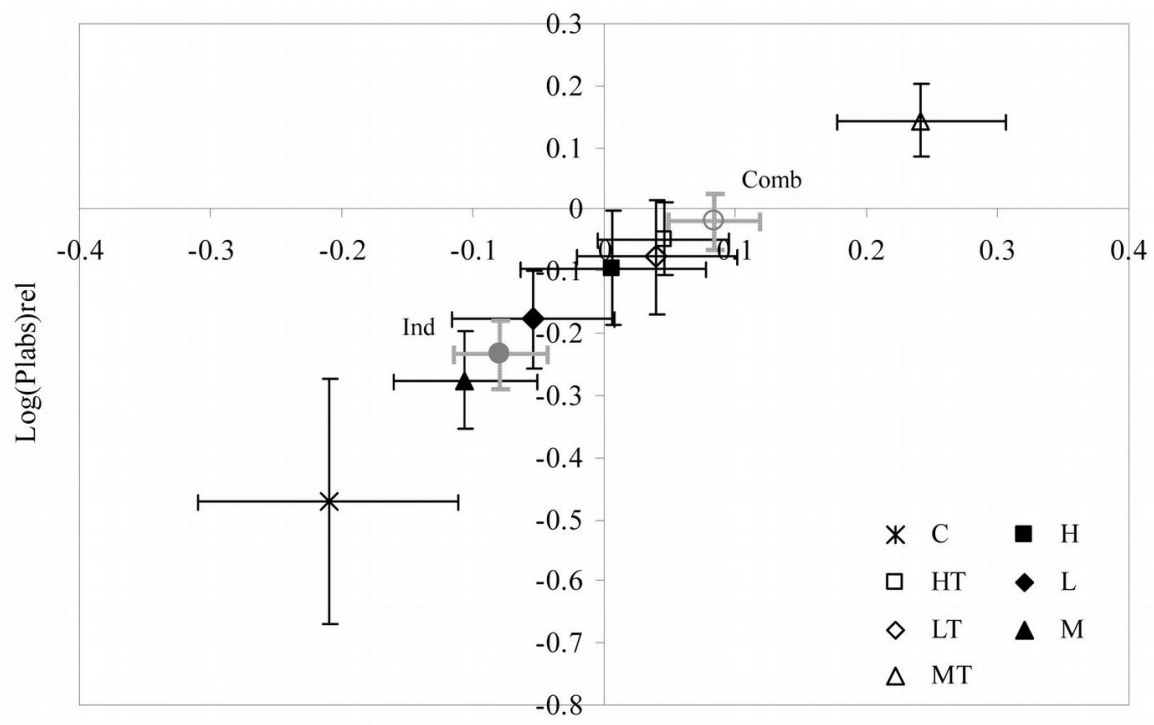

$(\mathrm{ETo} / \mathrm{ABS}) \mathrm{rel}$

Fig. 7 - Correlation between log function of the relative performance index and the relative yield of electron transport for the treatments considered. (C): control; $(\mathrm{H})$ : herbicide; (HT): herbicide + tree shelters; (L): cultivation; (LT): cultivation + tree shelters; (M): mulch; (MT): mulch + tree shelters; (Ind): H, L, and M pooled treatments (no shelter, weed control); (Comb): HT, LT, and MT pooled treatments (shelter, weed control). the second year (Fig. 6). Seasonal evolution of fluorescence parameters showed that the maximal photochemical efficiency $(\mathrm{Fv} / \mathrm{Fm})$ decreased (relative minima) during the summer periods. Similarly, a slight reduction was observed during the winter period, particularly in the treatments with no shelter protection. The highest values were observed in the combined tree shelter treatments during the winter and spring of 2004.

Similar results were observed for the ETo/ABS and DIo/ABS parameters, showing significant differences in winter and spring 2004 (Fig. 6). The curve trend of ETo/ABS was similar to that obtained for $\mathrm{Fv} / \mathrm{Fm}$. However, DIo/ABS values showed an inverse trend and "no-sheltered" weed control treatments obtained higher values than the combined weed control + tree shelter treatments. By contrast, sheltered treatments showed significant differences in $\mathrm{RC} / \mathrm{ABS}$ values during spring measurements (Fig. 6). Finally, Fig. 7 allows us to compare the sensitivity of two important parameters: photosynthetic driving force and relative electron transport activity. The correlation between Log (PIabs) rel and (ETo/ABS) showed that treatments were arranged in a straight line, where the most positive value of the relationship (high vitality) was obtained for the MT treatment and the most negative value (low vitality) was obtained for the $\mathrm{C}$ treatment. According to the above evidence, weed control treatments combined with tree shelter led to higher vitality than no-sheltered treatments.

\section{Discussion}

\section{Survival and aerial-root morphology}

The present study confirms the positive effects of the applied competition management techniques on tree seedlings' survival. Overall, the techniques tested (i.e., weed control and shelter) improved the survival rate compared to the control treatment (C) throughout the monitoring period. In the Mediterranean region, the response of seedlings to the presence of a shelter is not clear (Bellot et al. 2002, Oliet \& Jacobs 2007). However, our results suggested a synergetic complementary action between the protection exerted by the shelter (e.g., from wind, radiation) and the control of competition derived from the weed treatments, with a significant effect on the overall response compared with the control treatment, as reported by other authors (Navarro Cerrillo et al. 2005, Rey Benayas et al. 2005).

Complementary results obtained in the same research site (Ceacero et al. 2012) showed that soil gravel content is a key factor for seedling survival. According to these results, optimal reforestation sites are identified by gravel content $<5 \%$; transitional sites by $5 \% \leq$ gravel content $\leq 15 \%$ and excluded 
sites by gravel content $>15 \%$. Soil grave content caused severe water limitations, particularly in the first year after planting, which influenced the effectiveness of neighboring vegetation control techniques and shelter protection for successful seedling establishment. This could be the cause of the high mortality rate observed in the MT and $\mathrm{C}$ treatments, characterized by a high soil gravel content $(\mathrm{MT}=19 \% ; \mathrm{C}=24.5 \%)$ as reported by Ceacero et al. (2012).

Early development of a large taproot and a delayed shoot growth is typical of all oaks (Johnson et al. 2009). In our case, holm oak seedlings height increment was relatively higher than the diameter increment. Stem diameter has been related to carbohydrate storage and root growth (Rey Benayas et al. 2003). According to the above considerations, plants invested during the first year more resources in lengthening their stems and producing leaves than in support structures (e.g., secondary xylem and roots). This trend was more evident in shelter protected plants, especially those from the MT treatment, where the tree shelter stimulated plant height growth (Bellot et al. 2002, Navarro Cerrillo et al. 2005, Oliet \& Jacobs 2007 Pemán et al. 2010). Stimulation of seedlings height growth by the shelter may help seedlings to overcome more quickly the dominance exerted by weeds in the early stages of establishment, if light interception by surrounding vegetation is moderate (Laliberté et al. 2008)

However, the effect of the tree shelter on diameter growth was less evident. During the first years after the establishment, seedlings subjected to combined treatments (weed control + tree shelter) invested more resources in aerial growth than in root growth (Navarro Cerrillo et al. 2005, Oliet \& Jacobs 2007, Pemán et al. 2010). In 2003, the combined weed control and tree shelter treatments exhibited negative diameter growth rates due to the transplanting shock. This trend was partly changing in the second year after planting according to diameter increment data. Height and diameter growth are the first physiological processes affected by water stress (Larcher 2003) and plants rapidly adapt to environmental conditions as for growth. Our results showed that seedlings took up to 2 years to achieve a morpho-physiological adaptation to new site conditions, which may be key in determining seedling survival. In Mediterranean ecosystems, high resource mobilization capacity to support large growth during the wet season is a key process for seedling survival during the dry season (Villar-Salvador et al. 2012).

On the other hand, some studies (Puértolas et al. 2010) have shown that tube shelters do not reduce root growth in shade-tolerant Quercus ilex and that tree shelter influence on growth depends on the selection of a shelter with optimal light transmissivity for each species. Our study showed a lower root system development (area and volume) in weed treatments combined with shelters, so the optimal light transmissivity characteristics of the shelter could be improved in future experiences.

Finally, according to the average diameter root data, weed control treatments (particularly herbicide and cultivation) appeared to be associated with the development of strong main roots, conferring a certain advantage for metabolic reserves and also for water access due to root penetration into deep soil layers (Chirino et al. 2008, Grossnickle 2012).

Alternatively, root fibrosity analysis showed that shelter protected plants (combined treatments) could have a certain advantage over unprotected ones (individualized treatments) in their efficiency in capturing resources.

\section{Water status}

During the first year after planting (Fig. 4), holm oak seedlings did not effectively regulate the increase in water potential ( $\Psi_{\text {midday }}$ $\left.\Psi_{\text {dawn }}\right)$ when water deficit became more marked (more negative in $\Psi_{\text {dawn }}$ data). Our results indicate that oak seedlings did not regulate water loss in a completely effective way as a result of water stress, and therefore that plants did not properly adapt to site conditions, as supported by morphology data. Microclimatic tree shelter conditions may have contributed to reinforcing this behavior (Fig. 4). According to Rambal (1992), holm oak seedlings are expected to regulate their water consumption, tending to conserve soil water resources as the water deficit becomes more marked (Vilagrosa et al. 2003). General isohydric behavior of holm oak (as in other Mediterranean oak trees) could effectively control tissue dehydration via stomatal closure and deep rooting. This behavior was not recorded until the second year after planting (2004). Moreover, during the first year we observed that seedlings (especially those subjected to combined treatments) invested more resources in the aerial growth than in the root growth. This implies a greater demand for evapotranspiration and decreased ability to explore a large soil volume for water. However, water loss was partially controlled by stomatal closure. Indeed, daily photosynthesis curves in summer evidenced that the positive assimilation rate had been restricted to the first hours of the day, a circumstance normally related to control tissue dehydration via stomatal closure during midday, when water demand is maximized (data not shown).

Although anisohydric behavior of holm oak seedlings is not expected, planting shock during the pre-establishment phase may limit their morpho-physiological response (effec- tively stomatal closure and deep rooting) to water stress, leading to a poor-regulated water loss and the high mortality observed after the critical summer period of the first year (Oliet et al. 2012). Mediavilla \& Escudero (2004) reported that oaks seedlings at the early stage of establishment may adopt a less conservative water-use strategy than adult trees. Such evidence has been usually explained by a lack of acclimatization to the new site conditions as a consequence of poor root-soil contact. Two years after planting (in 2004), seedlings' response to water stress was more commensurate with site conditions as a result of the new root formation and growth after the planting shock. Rapid root growth is commonly associated with high plant vigor, high photosynthetic activity and total carbohydrate reserves available for root production; it is also a key trait for avoiding lethal water stress (Villar-Salvador et al. 2012, Grossnickle 2012). Chaar et al. (2008) considered that benefits of weed control mainly occur during the second year after establishment.

In this investigation, neither the weed control treatments nor the protection by tree shelters significantly affected seedling water status. However, during the spring (particularly in the first year) shelter protection may lower the water demand of seedlings and lessen their water stress (Fig. 1). Indeed, aerial plant growth increased in sheltered trees (Fig. 3). This is likely to determine a higher transpiration rate (increasing $\mathrm{RH}$ and reducing VPD) for plants inside the tree shelter in comparison to those outside. This phenomenon is appreciable when water availability is not a limiting factor (mean values for the spring period: $\mathrm{RH}_{\text {inside shelter }}=80.7 \%>$ $\mathrm{RH}_{\text {outside }}=69.5 \% ; \mathrm{VPD}_{\text {inside shelter }}=0.18 \mathrm{KPa}<$ $\mathrm{VPD}_{\text {outside }}=0.25 \mathrm{Kpa}-$ Oliet \& Jacobs 2007). During summer, conditions inside and outside the shelters did not differ to the extent of affecting plant water status. The absolute maximum temperature inside the shelter was only $2.4^{\circ} \mathrm{C}$ higher than outside; also, the absolute maximum value for VPD inside only differed by $0.5 \mathrm{KPa}$ when compared with the value outside. Navarro Cerrillo et al. (2005) obtained similar results with ventilated shelters.

\section{Gas exchange}

Shelter protection produced a significant effect on the net photosynthesis rate by reducing its seasonal oscillations. During the spring, water stress conditions were similar across all seedling treatments. According to Oliet \& Jacobs (2007) and Pemán et al. (2010), we hypothesized higher photosynthesis rates to be associated with a larger light availability. In fact, we found a positive and significant linear relationship between net photosynthesis rate and photosynthetic photon flux density $(\mathrm{F}=12.595 \mathrm{P}<0.001)$ in 
the spring. Moreover, a decrease in the photosynthetically active radiation was observed for seedlings under tree shelter (inside $\approx$ $60 \%$ outside - Navarro Cerrillo et al. 2005, Bergez \& Dupraz 2009).

During the summer, under similar water stress conditions inside and outside the shelters and without any relation between $A$ and $P P F D$, temperature becomes the main limiting factor of the photosynthesis rate (Close et al. 2009). Ogaya \& Peñuelas (2003) recorded $A$ values close to 0 when the temperature ranged between 34.8 and $36.5{ }^{\circ} \mathrm{C}$. In this study, temperatures over $35^{\circ} \mathrm{C}$ were reached just after the sunrise, particularly in tree shelters (greenhouse effect). Therefore, positive assimilation was restricted to the first hours of the day and may explain the low $A$ values obtained during summer for the combined treatments. Oliet \& Jacobs (2007) and Pemán et al. (2010) obtained similar results under controlled conditions.

Finally, an increase in the photosynthesis rate during the winter period could be favored by the tree shelter protection, as we observed in oak species under winter conditions. Gratani \& Bombelli (2000) showed that the photosynthesis rate in oak species decreases by $\approx 50 \%$ when temperature is below $6{ }^{\circ} \mathrm{C}$. Mean winter temperatures ranged between approximately 3 and $12{ }^{\circ} \mathrm{C}$ in the study area. Tree shelters lead to an increase in the assimilation rate of the combined treatments associated with a higher temperature inside the shelter (Navarro Cerrillo et al. 2005) and a decrease of leaf exposure to cold wind.

\section{Chlorophyll fluorescence}

In contrast with previous studies (Pemán et al. 2010), the protective effect of tree shelters deeply affected the chlorophyll fluorescence results obtained in this investigation. Tree shelter protection seems to limit the occurrence of photoinhibition processes in seedlings subjected to the combined treatments. Based on our results, the existence of a photoprotection mechanism may be hypothesized for exposed seedlings during the spring. Ogaya \& Peñuelas (2003) observed that sun oak leaves displayed a lower $\mathrm{Fv} / \mathrm{Fm}$ than shade leaves, and Valladares et al. (2000) reported that non-photochemical excess energy dissipation increased with the PPFD. These differences between sun and shade leaves can be compared to the light control exerted on PPFD by tree shelters (transmissivity range: $35-60 \%$, depending on the incidence angle of light beams - Bergez \& Dupraz 2009).

In the dry summer period, the protection provided by tree shelters did not prevent photoinhibition processes. The shoot morphology of the sheltered seedlings suggest that plants growth inside a tree shelter could develop a shade acclimation modulated by the intensity and the duration of shading (Pemán et al. 2010). Under the above conditions, direct radiation of the sun on sheltered seedlings (reached during the sun zenith) may have an effect similar to a sustained photoinhibition, analogous to that of sunflecks on seedlings under shady conditions (Valladares \& Pearcy 2002). Bergez \& Dupraz (2009) observed that when the sun reaches its zenith, the transmission coefficient of tree shelters is much lower than at any other time. Thus the protection provided by tree shelters can be limited and the photoinhibition processes may occur. The lower $\mathrm{CO}_{2}$ assimilation rate observed during the summer for protected plants seems to support this interpretation.

The winter period was especially crucial for oak seedlings under Mediterranean conditions. Cold stress may affect the photoinhibition processes in Mediterranean plants either by cold wind or by cold-induced reduction of water absorption (Oliveira \& Peñuelas 2004, Corcuera et al. 2005). According to previous studies (Oliveira \& Peñuelas 2002) a significant reduction in the maximum photochemical efficiency ( $\mathrm{Fv} / \mathrm{Fm})$ was observed for non-sheltered seedlings. This decrease was linked to a significant reduction in the efficiency of electron transport (ETo/ABS), as well as an increase in the energy dissipation rate at the PSII antenna (DIo/ABS). Such evidence is usually associated with a protective mechanism against winter stress (Baquedano \& Castillo 2006, Arena et al. 2008, Vitale et al. 2012). Tree shelter protection may have limited the severity of winter stress in protected seedlings, reducing their need for photoprotection. On the one hand, it may reduce the excess of irradiance on the plant (Oliet \& Jacobs 2007, Bergez \& Dupraz 2009); on the other hand, it may act on leaf withering due to the action of the wind. Gratani \& Bombelli (2000) recorded a decrease in the electron transport rate to half their maximum value at temperatures between 8 and $10^{\circ} \mathrm{C}$. In our study, mean ambient temperatures in the winter months ranged between 3 and $12{ }^{\circ} \mathrm{C}$, with a $2{ }^{\circ} \mathrm{C}$ difference between inside and outside the tree shelters.

Finally, vitality analysis (Fig. 7) confirmed that seedlings subjected to combined treatments (in particulat the MT treatment) had a greater photochemical yield than those subjected to individual treatments. In fact, the slope of the linear regression between $\log$ $(\mathrm{PIabs})_{\mathrm{rel}}$ and $(\mathrm{ETo} / \mathrm{ABS})_{\text {rel }}$ can be considered a property of the plants analyzed in relation to their transformation of the absorbed light energy into chemical energy aimed at metabolic reactions (Hermans et al. 2003).

Some additional considerations have to be done on the apparent contradiction between photosynthesis and fluorescence measurements. A negative response in photochemi- cal efficiency was not directly related to a decrease in the $\mathrm{CO}_{2}$ assimilation rate. Many authors consider that photoinhibition per se does not cause an impediment to photosynthesis. Instead, it reflects the action of several leaf protection processes to handle the excess of absorbed energy that cannot be fully utilized in the photochemical reactions (Adams \& Demmig-Adams 1995); thus, it is related with the plant adaptability to extant environmental conditions (Morales et al. 2002). Photoinhibition can be a qualitative indicator of various stresses that limit photosynthesis (Maxwell \& Johnson 2000), but no direct relationship between these processes was found in our study, accordingly to what reported in the literature (Adams \& Demmig-Adams 1995, Morales et al. 2002).

\section{Conclusions}

All the treatments tested for competition control strategies (i.e., cultivation, oxyfluorfen and mulch) were effective when compared to the control treatment, but no definitive results were obtained in order to establish generalized patterns of seedlings' response to the different treatments considered.

Nonetheless, tree shelter protection has proven to be a highly effective complement to weed control treatments in the restoration of degraded agroforestry systems in Mediterranean areas. In our study, tree shelter protection of seedlings determined a greater height growth, photosynthesis regulation, a likely improvement in winter gas exchange, a reduction in photoinhibition processes and seedling vitality enhancement from a photochemical point of view. Therefore, we recommend the adoption of an integrated strategy based on the combination of multiple techniques as a way to improve holm oak seedling establishment. Finally, the use of the combined techniques described above becomes beneficial starting from the second year after seedling establishment, when they overcome the transplanting stress.

\section{Acknowledgments}

The authors would like to thank the nursery Viveros San Jerónimo (Regional Ministry of the Environment of Andalusia, Spain) for providing the study plants and Victor Ortiz for arranging the research site at IFAPA Alameda del Obispo (Córdoba, Spain). The authors are grateful to L. Salmoral and to D. Ariza for their technical assistance. This study was supported by the coordinated projects of the Spanish Ministry of Education and Science entitled DECOVAR (AGL200912243-C02-02) and INTERBOS (CGL200804503-CO3-02) as well as European Regional Development Fund (ERDF).

\section{References}

Adams WW, Demmig-Adams B (1995). The xan- 
thophyll cycle and sustained thermal energy dissipation activity in Vinca minor and Euonymus kiautschovicus in winter. Plant, Cell and Environment 18: 117-127. - doi: 10.1111/j.13653040.1995.tb00345.x

Ammer C, Balandier P, Bentsen NS, Coll L, Löf M (2011). Forest vegetation management under debate: an introduction. European Journal of Forest Research 130: 1-5. - doi: 10.1007/s10342010-0452-6

Arena C, Vitale L, Virzo De Santo A (2008). Photosynthesis and photoprotective strategies in Laurus nobilis L. and Quercus ilex L. under summer drought and winter cold. Plant Biosystems 142 (3): 472-479. - doi: 10.1080/1126350 0802410819

Baquedano FJ, Castillo FJ (2006). Comparative ecophysiological effects of drought on seedlings of the Mediterranean watersaver Pinus halepensis and water-spenders Quercus coccifera and Quercus ilex. Trees 20: 689-700. - doi: 10.1007/ s00468-006-0084-0

Bellot J, Ortiz de Urbina JM, Bonet A, Sánchez JR (2002). The effects of tree shelters on the growth of Quercus coccifera L. seedlings in a semiarid environment. Forestry 75 (1): 89-106. doi: 10.1093/forestry/75.1.89

Bergez JE, Dupraz ZC (2009). Radiation and thermal microclimate in tree shelter. Agricultural and Forest Meteorology 149: 179-186. - doi: 10.1016/j.agrformet.2008.08.003

Ceacero CJ, Díaz-Hernández JL, del Campo A, Navarro-Cerrillo RM (2012). Interactions between soil gravel content and neighboring vegetation control management in oak seedling establishment success in Mediterranean environments. Forest Ecology and Management 271: 10-18. doi: 10.1016/j.foreco.2012.01.044

Chaar H, Mechergu T, Khouaja A, Abid H (2008). Effects of treeshelters and polyethylene mulch sheets on survival and growth of cork oak (Quercus suber L.) seedlings planted in northwestern Tunisia. Forest Ecology and Management 256 (4): 722-731. - doi: 10.1016/j.foreco. 2008.05.027

Chirino E, Vilagrosa A, Hernández EI, Matos A, Vallejo VR (2008). Effects of a deep container on morphofunctional characteristics and root colonization in Quercus suber L. seedlings for reforestation in Mediterranean climate. Forest Ecology and Management 256: 779-785. - doi: 10.1016/j.foreco.2008.05.035

Close DC, Ruthrof KX, Turner S, Rokich DP, Dixon KW (2009). Ecophysiology of species with distinct leaf morphologies: effects of plastic and shadecloths guards. Restoration Ecology 17: 33-41. - doi: 10.1111/j.1526-100X.2007.0033 $0 . \mathrm{x}$

Corcuera L, Morales F, Abadía A, Gil-Pelegrín E (2005). Seasonal changes in photosynthesis and photoprotection in a Quercus ilex subsp. ballota woodland located in its upper altitudinal extreme in the Iberian Peninsula. Tree Physiology 25 (5): 599-608. - doi: 10.1093/treephys/25.5.599

Dahiya R, Ingwersen J, Streck T (2007). The effect of mulching and tillage on the water and temperature regimes of a loess soil: Experimental findings and modelling. Soil and Tillage Research 96: 52-63. - doi: 10.1016/j.still.2007.02.004 Dupraz C, Newman SM (1997). Temperate agroforestry: the European way. In: "Temperate agroforestry systems" (Gordon AM, Newman SM eds). CAB International, Wallingford, UK, pp. 181-236. [online] URL: http://www.cabdirect. org/abstracts/19970608009.html

Gratani L, Bombelli A (2000). Correlation between leaf age and other leaf traits in three Mediterranean maquis shrub species: Quercus ilex, Phillyrea latifolia and Cistus incanus. Environmental and Experimental Botany 43: 141153. - doi: 10.1016/S0098-8472(99)00052-0

Grossnickle SC (2012). Why seedlings survive: influence of plant attributes. New Forests 43: 711-738. - doi: 10.1007/s11056-012-9336-6

Hermans C, Smeyers M, Rodriguez RM, Eyletters M, Strasser RJ, Delhaye JP (2003). Quality assessment of urban trees: a comparative study of physiological characterization, airborne imaging and on site fluorescence monitoring by the O-J-IP-test. Journal of Plant Physiology 160: 81-90. doi: 10.1078/0176-1617-00917

Johnson PS, Shifley SR, Rogers R (2009). The ecology and silviculture of oaks ( $\left.2^{\text {nd }} \mathrm{edn}\right) . \mathrm{CABI}$ Publishing International, Oxford, UK, pp. 600. [online] URL: http://books.google.it/books?id= 2Wxy8enI7zMC

Kurstjens DAG (2007). Precise tillage systems for enhanced non-chemical weed management. Soil and Tillage Research 97: 293-305. - doi: 10.1016 /j.still.2006.06.011

Laliberté E, Bouchard A, Cogliastro A (2008). Optimizing hardwood reforestation in old-fields: the effects of treeshelters and environmental factors on tree seedling growth and physiology. Restoration Ecology 16: 270-280 - doi: 10.1111/ j.1526-100X.2007.00270.x

Larcher W (2003). Physiological plant ecology: ecophysiology and stress physiology of functional groups. Springer Verlag, Heidelberg, Berlin, Germany, pp. 513. [online] URL: http://books.google.it/books?id=BgtzD4frr98C

Löf M, Dey DC, Navarro RM, Jacobs DF (2012). Mechanical site preparation for forest restoration. New Forests 43: 825-848. - doi: 10.1007/ s11056-012-9332-x

Maestre FT, Callaway RM, Valladares F, Lortie C (2009). Refining the stress-gradient hypothesis for competition and facilitation in plant communities. Journal of Ecology 97: 199-205. - doi: 10.1111/j.1365-2745.2008.01476.x

Maldonado-Rodríguez R (1999). Biolyzer software. Laboratory of Bioenergetics, University of Geneva, Switzerland. [online] URL: http://www. geocities.ws/fluoromatics/mysoftware.html

Maxwell K, Johnson G (2000). Chlorophyll fluorescente. A practical guide. Journal of Experimental Botany 51: 659-668. - doi: 10.1093/ jexbot $/ 51.345 .659$

Mediavilla S, Escudero A (2004). Stomatal responses to drought of mature trees and seedlings of two co-occurring Mediterranean oaks. Forest Ecology and Management 187: 281-294. - doi: 10.1016/j.foreco.2003.07.006

Morales F, Abadia A, Abadia J, Montserrat G, Gil-Pelegrín E (2002). Trichomes and photosynthetic pigment composition changes: responses of Quercus ilex subsp. ballota (Desf.) Samp. and Quercus coccifera L. to Mediterranean stress conditions. Trees 16: 504-510. - doi: 10.1007/ s00468-002-0195-1

Navarro Cerrillo RM, Ariza D, Gonzalez L, del Campo A, Arjona M, Ceacero C (2009). Legume living mulch for afforestation in agricultural land in southern Spain. Soil and Tillage Research 102: 38-44. - doi: 10.1016/j.still.2008.07.013

Navarro Cerrillo RM, Fragueiro B, Ceacero C, del Campo A, de Prado R (2005). Establishment of Quercus ilex L. subsp. ballota Desf. Samp. using different weed control strategies in southern Spain. Ecological Engineering 25: 332-342. doi: 10.1016/j.ecoleng.2005.06.002

Ogaya R, Peñuelas J (2003). Comparative field study of Quercus ilex and Phillyrea latifolia photosynthetic response to experimental drought conditions. Environmental and Experimental Botany 50: 137-148. - doi: 10.1016/S0098-8472 (03)00019-4

Oliet JA, Artero F, Cuadros S, Puértolas J, Luna L, Grau JM (2012). Deep planting with shelters improves performance of different stocktype sizes under arid Mediterranean conditions. New Forests 43: 925-939. - doi: 10.1007/s11056-0129345-5

Oliet J, Jacobs DF (2007). Microclimatic conditions and plant morph-physiological development within a tree shelter environment during establishment of Quercus ilex seedlings. Agricultural and Forest Meteorology 144: 58-72. - doi: 10.1016/j.agrformet.2007.01.012

Oliveira G, Peñuelas J (2002). Comparative protective strategies of Cistus albidus and Quercus ilex facing photoinhibitory winter conditions. Environmental and Experimental Botany 47: 281-289 - doi: 10.1016/S0098-8472(02)00003-5 Oliveira G, Peñuelas J (2004). Effects of winter cold stress on photosynthesis and photochemical efficiency of PSII of two Mediterranean Cistus albidus and Quercus ilex. Plant Ecology 175: 179-191. - doi: 10.1007/s11258-005-4876-x

Olivera A, Fischer CR, Bonet JA, Martínez de Aragón J, Oliach D, Colinas C (2011). Weed management and irrigation are key treatments in emerging black truffle (Tuber melanosporum) cultivation. New Forests 42 (2): 227-239. - doi: 10.1007/s11056-011-9249-9

Pemán J, Peguero-Pina JJ, Valladares F, Gil-Pelegrín $\mathrm{E}$ (2010). Evaluation of unventilated tree shelters in the context of Mediterranean climate: Insights from a study on Quercus faginea seedlings assessed with a 3D architectural plant model. Ecological Engineering 36 (4): 517-526. - doi: 10.1016/j.ecoleng.2009.11.021

Plieninger T (2007). Compatibility of livestock grazing with stand regeneration in Mediterranean holm oak parklands. Journal for Nature Conservation 15: 1-9. - doi: 10.1016/j.jnc.2005.09.002 Puértolas J, Oliet JA, Jacobs DF, Benito LF, Peñuelas $J$ (2010). Is light the key factor for suc- 
cess of tube shelters in forest restoration plantings under Mediterranean climates? Forest Ecology and Management 260: 610-617. - doi 10.1016/j.foreco.2010.05.017

Rambal S (1992). Quercus ilex facing water stress: a functional equilibrium hypothesis. Vegetatio 99-100: 147-153. - doi: 10.1007/BF0011 8220

Regent Instruments (1998). WinRhizo V3.10b software. Regent Instruments Inc., Quebec, Canada.

Rey Benayas JM, Espigares T, Castro-Díez P (2003). Simulated effects of herb competition on planted Quercus faginea seedlings in Mediterranean abandoned cropland. Applied Vegetation Science 6: 213-222. - doi: 10.1658/1402-2001 (2003)006[0213:SEOHCO]2.0.CO;2

Rey Benayas JM, Navarro J, Espigares T, Nicolau JM, Zavala MA (2005). Effects of artificial shading and weed mowing in reforestation of Mediterranean abandoned cropland with contrasting Quercus species. Forest Ecology and Management 212: 302-314. - doi: 10.1016/j. foreco.2005. 03.032

Rivest D, Rolo V, López-Díaza L, Moreno G (2011). Shrub encroachment in Mediterranean silvopastoral systems: Retama sphaerocarpa and Cistus ladanifer induce contrasting effects on pasture and Quercus ilex production. Agricultu- re, Ecosystems and Environment 141: 447- 454. South DB, Zwdinski JB, Kotze H (2001). Early growth responses from weed control and planting large stockes of Pinus radiata are greater than that obtained from mechanical soil cultivation. New Forests 22: 199-211. - doi: 10.1023/A:1015 648605949

SPSS Inc. (2003). SPSS v.12.0 software. Chicago, Illinois, USA.

Strasser RJ, Srivastava A, Tsimilli-Michael M (2000). The fluorescence transient as a tool to characterize and screen photosynthetic samples. In: "Probing Photosynthesis: Mechanisms, Regulation and Adaptation" (Yunus M, Pathre U, Mohanty $\mathrm{P}$ eds). Taylor and Francis, London, UK, pp. 445-483.

Thompson DG, Pitt DG (2003). A review of Canadian forest vegetation management research and practice. Annals of Forest Science 60: 559572. - doi: 10.1051/forest:2003060

Valladares F, Martínez-Ferri E, Balaguer L, PérezCorona E, Manrique E (2000). Low leaf-level response to light and nutrients in Mediterranean evergreen oaks: a conservative resource-use strategy? New Phytologist 148: 79-91. - doi: 10.1046/j.1469-8137.2000.00737.x

Valladares F, Pearcy RW (2002). Drought can be more critical in the shade than in the sun: a field study of carbon gain and photo-inhibition in a
Californian shrub during a dry El Niño year. Plant, Cell and Environment 25: 749-759. - doi: 10.1046/j.1365-3040.2002.00856.x

Villar-Salvador P, Puértolas J, Cuesta B, Peñuelas JL, Uscola M, Heredia-Guerrerom N, Rey Benayas JM (2012). Increase in size and nitrogen concentration enhances seedling survival in Mediterranean plantations. Insights from an ecophysiological conceptual model of plant survival. New Forests 43: 755-770. - doi: 10.1007/s11056-0129328-6

Vilagrosa A, Bellot J, Vallejo VR, Gil-Pelegrín E (2003). Cavitation, stomatal conductance, and leaf dieback in seedlings of two co-occurring Mediterranean shrubs during an intense drought. Journal of Experimental Botany 54: 2015-2024. - doi: 10.1093/jxb/erg221

Vitale L, Arena C, Virzo De Santo (2012). Seasonal changes in photosynthetic activity and photochemical efficiency of the Mediterranean shrub Phillyrea angustifolia L. Plant Biosystems 146 (2): 443-442. - doi: 10.1080/11263504.2011.651 507

Willoughby I, Balandier P, Bentsen NS, McCarty $\mathrm{N}$, Claridge J (2009). Forest vegetation management in Europe: current practice and future requirements. COST Office, Brussels, Belgium, pp. 156. 